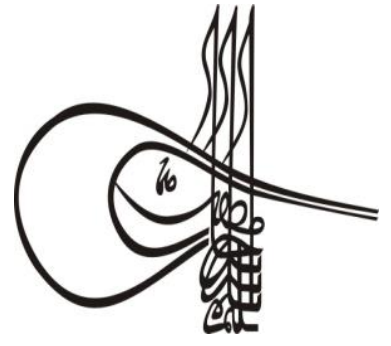

Received/Geliş: 20.06.2019

\section{Turkigh Studies \\ Social Sciences}

Volume 14 Issue 4, 2019, p. 1737-1758

DOI: 10.29228/TurkishStudies.23379

ISSN: 2667-5617

Skopje/MACEDONIA-Ankara/TURKEY

Research Article / Araştırma Makalesi

Article Info/Makale Bilgisi

\title{
ÖĞRENCİ BAKIŞ AÇISIYLA MUHASEBE EĞİTİMİNDE TEKNOLOJİ KULLANIMI: HİTİT ÜNİVERSİTESİ ÖRNEĞİ
}

\author{
Nurcan SÜKLÜM*
}

\begin{abstract}
öz
Günümüz muhasebe uygulamaları teknoloji yoğun bir dönemden geçtiği için, muhasebe uygulayıcılarının da bu sürece uyum sağlaması gerekmektedir. Bu noktada geleceğin muhasebe uygulayıcıları olarak muhasebe dersi alan, İktisadi ve İdari Bilimler Fakülteleri ve Meslek Yüksekokulu öğrencilerinin aldıkları teknoloji destekli muhasebe eğitimi önem arz etmektedir. Bu çalışmanın amacı, öğrencilerin muhasebe derslerinde teknoloji kullanımına ilişkin bakış açılarının tespit edilmesidir. Bu amaçla Hitit Üniversitesi bünyesindeki İktisadi ve İdari Bilimler Fakültesinde ve Meslek Yüksekokullarında muhasebe dersi alan öğrencilere yönelik bir anket çalışması yapılmıştır. Çalışma sonucunda öğrencilerin bölümleri, ortalamaları ve sınıfları ile muhasebe derslerinde teknoloji kullanımına yönelik bakış açıları arasında anlamlı bir fark bulunmuştur. Ayrıca, çalışmada öğrencilerin sırasıyla en çok muhasebe yazılımlarının ayrı bir ders olarak anlatılması gerektiği, muhasebe derslerinde ders konularının sinifta anlatıldıktan sonra konu ile ilgili ders notlarının internet ortamında da paylaşılması gerektiği, muhasebe dersleri veren öğretim üyelerinin eğitimle ilgili yeni teknolojileri takip etmesi gerektiği ve teknolojik ürünlerin kullanımı ile dersleri takip etmenin daha kolay olacağ ifadelerine önem verdikleri tespit edilmiştir. Çalışmanın bir başka sonucu ise, öğrenciler derslerde daha çok taşınabilir bilgisayar, projeksiyon cihazı ve akıllı tahta kullanılması gerektiğini belirtmişler, aynı şekilde teknolojik yazılımlardan ise, paket muhasebe yazılımları, ofis uygulamaları ve internet tabanlı yazılımların kullanılması gerektiğini belirtmişlerdir.
\end{abstract}

Anahtar Kelimeler: Muhasebe Dersi, Teknoloji, İİBF Öğrencileri, MYO Öğrencileri 


\title{
USE OF TECHNOLOGY IN ACCOUNTING EDUCATION FROM THE PERSPECTIVE OF STUDENTS: THE CASE OF HITIT UNIVERSITY
}

\begin{abstract}
Since today's accounting practices are going through a technology intensive period, the practitioners of accounting are also required to adapt to this process. At this point, technology-assisted accounting education which is received by the students of Faculties of Economics and Administrative Sciences and Vocational Schools of Higher Education who are taking accounting course as future accounting practitioners is important. The aim of this study is to determine students' perspectives on the use of technology in their accounting courses. To this end, a questionnaire study was conducted for students who are taking accounting courses in Faculty of Economics and Administrative Sciences and Vocational Schools of Higher Education within Hitit University. As a result of the study, a significant difference was found between students' departments, their averages and classes and their perspective on the use of technology in accounting courses. In addition, as a result of the study it was determined that the students respectively attach importance to the issues such as; it is necessary to explain accounting software as a separate course, the course notes should also be shared on the internet after the course topics are explained during the accounting classes in the classroom, and the lecturers who give accounting courses should follow the new technologies related to education and it would be easier to follow the lessons with the use of technological products. Another result of the study was that students stated that more portable computers, projection devices and smart boards should be used in the courses. Similarly, they also mentioned that package accounting software, office applications and internet-based software among technological software should be used.
\end{abstract}

\section{STRUCTURED ABSTRACT}

In today's business world where information is shared digitally, the enterprises have to integrate this system as well. Accounting systems, which is one of the important systems for the enterprises, are going through a period that has started with the use of package software and technological applications such as e-declaration, e-invoice and e-book are used today. It is of great importance that professionals carrying out the accounting practices are able to use these technologies. Technological applications are generally learned and applied in active business life. However, the fact that the universities could support the accounting courses given in undergraduate or associate degree programs with the use of technology will make a positive contribution to the prospective professional students' acquaintance with the use of technology in accounting applications in advance.

In the study conducted in order to evaluate the perspectives of the students who take accounting course on the use of technology in accounting classes, the students who participated in the survey stated 
that more portable computers, projection devices and smart boards should be used in the courses. Similarly, they also mentioned that package accounting software, office applications and internet-based software among technological software should be used.

The students participating in the survey were asked whether they would like to work in the field of accounting in the future and it was determined that the number of those who answered yes, those who answered no, and those who stated that they were uncertain were close to each other. The majority of the students stated that they do not want to take accounting courses by distance education method. This shows that students believe that accounting courses should be taught by face to face method.

Another finding of the study is that almost all of the students participating in the survey have smart phones and the majority of them have personal computers. The majority of the students stated that they have wireless internet facility in their universities, but it is seen that the ratio of those who say yes to those who say no is close to each other when considering the aspect of benefiting from this service. The students were asked whether they utilized the websites while studying accounting courses and exams and the results were very close to each other. In other words, the students participating in the survey do not benefit from internet service while studying accounting courses and exams although they have internet access. This shows that students are reluctant to use technology while studying accounting and exams. It is seen that the share of accounting package programs in the curriculum of accounting education in our country is generally insufficient. The fact that the majority of the students participating in the survey stated that they do not use an accounting package program can be considered as a supportive finding.

In addition, as a result of the study it was determined that the students participating in the survey respectively attach importance to the issues such as; it is necessary to explain accounting software as a separate course, the course notes should also be shared on the internet after the course topics are explained during the accounting classes in the classroom, and the lecturers who give accounting courses should follow the new technologies related to education and it would be easier to follow the lessons with the use of technological products. Another aspect of the use of technology in accounting courses is the use of the game method. In the study, the students who participated in the survey stated that the use of the game method in the accounting courses and exams would increase the success, albeit at a low rate. This shows that the awareness about the use of the game method in accounting education has not developed yet.

In the study, a statistically significant difference was found between students' departments, their averages and classes and their perspective on the use of technology in accounting courses. In other words, whether the students are undergraduate or associate degree students or their responses according to the department they study differ significantly. Likewise, students' opinions about the use of technology in accounting change significantly depending on whether students have a low or high average. Also, whether the students

\section{Turkish Studies - Social Sciences}

Volume 14 Issue 4, 2019 
participating in the survey are in the first grade or have reached the graduation stage significantly changes their answers in the survey.

As a result, considering the importance of using technology in the execution of accounting applications today, it is necessary to give the necessary importance to the use of technology in accounting education given in universities and the curriculum should be adapted accordingly.

Keywords: Accounting Course, Technology, Students of Faculty of Economics and Administrative Sciences, Students of Vocational Schools of Higher Education.

\section{Giriş}

Dünyada yaşanan teknolojik değişimleri, endüstri 1.0 ve endüstri 5.0 arasında yaşanan dönemler bazında incelemek mümkündür. $\mathrm{Bu}$ değişimler, endüstri 1.0 olarak adlandırılan Sanayi Devrimiyle başlamış, Endüstri 2.0 (İkinci Sanayi Devrimi) olarak bildiğimiz elektrik kullanımıyla seri üretime geçiş süreciyle devam etmiştir. Bunu Endüstri 3.0 (üçüncü sanayi devrimi) denilen dijital devrim yani bilgi teknolojilerinin kullanımı takip etmiştir. İnternetin ve yapay zekanın yoğun olarak kullanıldığı, siber fiziksel sistemlerin olduğu dönem endüstri 4.0 (dördüncü sanayi devrimi) olarak adlandırılmış ve günümüzde teknolojinin bir tehdit olarak değil bir yardımcı olarak algılanması gerektiği felsefesine dayanan toplum 5.0 olarak da bilinen endüstri 5.0 dönemi konuşulmaya başlanmıştır.

Yaşanan bu çarpıcı teknolojik gelişmeler işletmelerde neredeyse tüm sistemlerde kendini göstermektedir. Bunlardan birisi de muhasebe bilgi sistemidir. Muhasebe sisteminde de paket programların kullanılmaya başlamasıyla teknoloji kullanılmaya başlanmış, günümüzde de e-fatura, ebeyanname, e-defter gibi teknolojik devrimler yaşanmaktadır.

Elbette muhasebe sistemi içerisinde uygulayıcıların yani meslek mensuplarının yaşanan bu teknolojik değişimlere uyum sağlaması gerekmektedir. Bu noktada meslek hayatına başlamadan önce aldıkları eğitim esnasında muhasebe derslerinin teknoloji destekli olup olmadı̆̆ önem kazanmaktadır. Öğrencilerin muhasebe derslerini teknoloji destekli almaları mesleklerini icra ederken teknolojiye uyum sağlamalarını kolaylaştıracaktır.

$\mathrm{Bu}$ çalışmada öğrencilerin muhasebe eğitiminde teknoloji kullanımına bakış açılarının tespit edilmesi amaçlanıştır. $\mathrm{Bu}$ amaçla Hitit Üniversitesi bünyesindeki İktisadi ve İdari Bilimler Fakültesinde ve Meslek Yüksekokullarında muhasebe eğitimi alan öğrencilere yönelik bir anket çalışması yapılmıştır.

\section{Muhasebe Eğitimi ve Teknoloji}

Dünyada ülkeler arasındaki sınırların kalkması, pazar ekonomisi, rekabet, uzmanlaşma, bilişim ve iletişim teknolojilerindeki gelişmeler ve hızla değişen koşullar gibi faktörler karar alma süreçlerinde doğru bilgiye hızla ulaşmayı gerektirmektedir. Bu koşullarda en doğru bilgiye en hızlı şekilde ulaşanlar rekabet avantajına sahip olabilmektedirler. Bilginin hızlı bir şekilde üretilmesi ve iletilmesinde teknolojinin payı büyüktür. Bilgi teknolojilerinde yaşanan gelişmeler, ekonomik, sosyal ve kültürel alanlarda devrim niteliğinde bir süreci beraberinde getirmiştir. Bunun sonucu olarak da geleceğin muhasebe uygulayıcıları olan muhasebe dersi alan öğrencilerin de küreselleşen dünyaya ayak uydurmaları gerekmektedir (Hacırüstemoğlu, 2008: 4). Bunun için de alınan muhasebe eğitimi oldukça önemlidir.

Muhasebe eğitiminin temel amacı; finansal bilgilerin hatasız ve objektif olarak kullanılması ve muhasebe bilgisinin sunumu sırasında ilgili tarafların eğitimi ve uygulamaların da buna göre 
şekillendirilmesidir. Muhasebe eğitimi, muhasebe mesleğinin uygulanması bakımından önemlidir. Dolayısıyla muhasebe eğitiminin mevcut hali ve özelliği, muhasebe mesleğinin toplum tarafindan algılanışına etki etmektedir. Mesleğin günümüz dünyasında iyi bir yer edinmesi için kaliteli bir eğitim verilmesi oldukça önemlidir. Muhasebe eğitiminin gelişimine etki eden faktörler oldukça çeşitlidir (Seyhan ve Kutlu, 2017: 784). Bunun için de belirlenmiş standartlara ve gelişmelere uyum sağlamak önem kazanmaktadır.

Global olarak uluslararası muhasebe standartlarının uygulanmasının yaygınlaşması ile muhasebe eğitimi uluslararası standartlar düzeyine ulaşmış ve Uluslararası Muhasebeciler Federasyonu (IFAC: International Federation of Accountants) bünyesinde Uluslararasi Muhasebe Eğitim Standartları Kurulu (IAESB: International Accounting Education Standart Board) kurulmuştur. Kuruluş, muhasebe eğitiminde uyulması gereken teknik ve mesleki kabiliyetler, etik uygulamalar konusunda standartlar belirlemektedir. Bu sayede tüm dünyada Uluslararası Muhasebe Eğitim Standartlarının uygulanmasi hedeflenmektedir. IAESB tarafindan 2005 yılinda standartlar yayınlanmaya başlamış ve 2015 yılı itibariyle 8 standart uygulamaya konulmuştur. Standarda yer alan 18. Maddede, muhasebe bilgilerinin teknolojiyle uyum içinde bulunmasının profesyonel muhasebe mesleğinin başarılı olmasında önemli etki sağlayacağı belirtilmektedir. (Can ve Demirci, 2016: 320). Standartta da belirtildiği gibi muhasebe eğitiminin teknolojiye dayalı olması, değişen koşullara uyum sağlama açısından oldukça önemlidir.

Muhasebe mesleğinin teknoloji ile olan ilişkisi, mesleğin uygulanması esnasında kullanılan teknolojik ürünler, değişimler ve mesleki eğitim esnasında yararlanılan teknolojiler olmak üzere iki açıdan değerlendirilebilir. Teknolojik gelişmeler muhasebe uygulamalarındaki birçok yöntemi değiştirmiş ve e- muhasebe dönemi başlamıştır (Erol Fidan vd., 2015: 35).

Muhasebe eğitiminin teknoloji ile desteklenmesi ve öğrencilerin gelecek konusunda donanımlı olmaları gerekmektedir. Mevcut teknolojik ortamda, muhasebe eğitiminin de bu ortama uygun olarak düzenlenmesi zorunluluk haline gelmiş̧ir (Erol Fidan ve Subaş1, 2015: 92).

\section{Literatür Taraması}

Hatunoğlu (2006) çalışmasında, öğrencilerin çoğunluğu, öğretim elemanlarının derste teknolojik araç kullandıklarını ama kendilerine kullanma olanağı verilmediğini belirtmişlerdir. Ayrıca öğrencilerin tamamına yakını, aktif eğitim-öğretimin ve uygulamalı eğitimin gerçekleşmesi gerektiğini, yarısına yakını ise, üniversitelerinde verilen muhasebe eğitimini olması gerekenden düşük düzeyde bulduklarını ifade etmişlerdir.

Bekçi ve arkadaşlarının (2006) Süleyman Demirel Üniversitesi İktisadi ve İdari Bilimler Fakültesi ile Süleyman Demirel Üniversitesi'ne bağlı Meslek Yüksek Okullarında öğrenim gören öğrencilerin bilgisayarlı muhasebe dersine bakış açılarını değerlendirmek amacıyla yaptıkları çalışmada, genel olarak öğrencilerin bilgisayarlı muhasebe dersinden memnun olduklarını ve bu dersin kendilerine okul sonrası yaşamlarında da işlerine yarayacağını belirttiklerini tespit etmişlerdir.

Çankaya ve Dinç (2009) muhasebe derslerini powerpoint ve klasik yöntemle alan öğrenciler arasında, başarı, ilgi, alg1 ve yargı açısından bir farklılık olup olmadığını tespit etmek amacıyla yaptıkları çalışmada, akademik başarı, algı ve yargı açısından powerpoint ile ders gören öğrencilerin klasik yöntemle ders alanlara göre daha başarılı ve olumlu düşüncelere sahip olduklarını ve iki grup arasındaki bu farklılığın istatistiki olarak anlamlı olduğunu, ancak ilgi açısından, iki grup arasında istatistiki olarak anlamlı bir farklılık olmadığını tespit etmişlerdir.

Erol Fidan (2012) muhasebe derslerini powerpoint ve klasik usulde alan öğrencilerin alg1 ve yargı açısından aralarında istatistikî bir farklılık olup olmadığını tespit etmek amacıyla yaptığı çalışmasında, algı ve yargı açısından klasik usulde ders alan öğrencilerin powerpoint ile ders gören öğrencilere göre muhasebe dersi hakkında daha olumlu düşüncelere sahip olduklarını tespit etmiştir.

\section{Turkish Studies - Social Sciences}

Volume 14 Issue 4, 2019 
Kızıl ve arkadaşlarının (2014) bilgi teknolojilerinin ve bilgisayar kullanımının öğrencilerin muhasebe dersindeki başarısına etkisinin değerlendirilmesi amacıyla yaptıkları çalışmada, öğrencilerin büyük bir çoğunluğunun bilgi teknolojilerini eğitimde desteklerken, diğer taraftan eski klasik yöntemi savunan bir kitlenin de bulunduğunu, bir kısım öğrencinin muhasebe derslerinin çoğunlukla bilgisayar uygulamalı olarak işlenmesi gerekliliğini savunurken, bir kısım öğrencinin ise bunun tam tersi bir şekilde düşündügünü, öğrencilerin büyük bir çoğunluğunun ise, üniversitelerde bilgisayarlı muhasebe laboratuvarlarının kurulması hususunu desteklediğini tespit etmişlerdir. Ayrıca öğrencilerin bilgi teknolojileri kullanımının muhasebe derslerini daha anlaşılır kıldığını, sınav sonuçlarına olumlu katkı yaptığını düşündüklerini tespit etmişlerdir.

Yüksel ve Olpak (2014) bir sosyal ağ olan Facebook'un muhasebe eğitiminde kullanımına yönelik öğrenci görüşlerini belirlemek amacıyla yaptıkları çalışmada, derste Facebook uygulamasının kullanımının; faydalı bir uygulama olması, dersin tekrar edilmesinde faydalı olması, iletişim imkânı sağlaması, dersi ilginç kılması ve farklı bir deneyim olması gibi olumlu özellikleri sayesinde öğrencilerin çoğunluğunun aldıkları eğitiminden memnun kaldıklarını tespit etmişlerdir.

Cameron and Dickfos (2014) muhasebe eğitiminde sözlü iletişimin ve kamera ve video yönteminin etkisini incelemek amacıyla yaptıkları çalışmada, özellikle, kullanılan video teknolojisinin daha fazla öz farkındalık sağladığı ve öğrencilerin öz becerileri ile beceri seviyesini arttırdığını tespit etmişlerdir.

Erol Fidan ve arkadaşları (2015), yaptıkları çalışmada öğrenciler, muhasebe derslerinde teknolojik ürünlerin ve paket programların kullanılmasını istediklerini ve en fazla sunum programları ve sosyal medya araçlarının kullanıldığını belirtmiştir. Ayrıca, öğrencilerin teknolojik ürünlere sahiplik oranları yüksek olmakla birlikte muhasebe derslerine ve sınavlarına hazırlanırken teknolojik ürünlerden yararlanmadıkları tespit edilmiştir. Öğrenciler muhasebe dersleri veren öğretim elemanlarının eğitimle ilgili güncel teknolojileri kullanmaları gerektiğini düşündüklerini ifade etmişler, fakat muhasebe derslerinin uzaktan eğitim yöntemi ile ile anlatılmasına sıcak bakmadıklarını belirtmişlerdir. Öğrenciler, teknoloji kullanımı ile muhasebe derslerinde başarı ve ilginin artacağı, muhasebe derslerini sevdireceği ve anlamayı kolaylaştıracağ 1 konusundaki düşünceleri hakkında kararsız oldukları tespit edilmiştir.

Eloff (2016) öğrencilerin bilgi teknolojisi yeterlilik becerisinin finansal muhasebe dersi üzerindeki etkisini ölçmek amacıyla bir excel modeli geliştirerek gerçekleştirdiği çalışmada, modelin öğrencilerin finansal muhasebe anlayışını geliştirdiğini tespit etmiştir.

Güneş ve arkadaşları (2017), çalışmalarında öğrencilerin teknolojiye yönelik tutumlarının okudukları bölümlere göre anlamlı düzeyde değişmediğini tespit etmişlerdir. Bununla birlikte öğrencilerin tutumlarının; cinsiyet, kendilerine ait bilgisayar olup olmaması, internet erişim imkanı ve internet kullanım süreleri açısından anlamlı farklılık göstermediği de bir diğer tespit edilen bulgudur.

Öztürk ve Kutlu (2017) Kafkas Üniversitesi öğrencileri üzerinde yaptıkları çalışmalarında, öğrencilerin çoğunluğu muhasebe derslerinin bilgisayar, projeksiyon cihazı ve akıllı tahta gibi teknolojik cihazlarla desteklenerek anlatılması gerektiğini belirtmişlerdir. Ayrıca, yazılım aracı olarak ise en fazla "İnternet Tabanl 1 Muhasebe Yaz1lım Programları", "Paket Muhasebe Yaz1lım Programları" ve "Ofis Uygulamaları" nın kullanılması gerektiğini tespit etmişlerdir.

Temelli (2018), lisans düzeyinde muhasebe eğitimi alan ve geleceğin muhasebecisi olabilecek meslek mensubu adayları olan İ̈BF öğrencilerinin aldıkları muhasebe derslerinde teknolojiden ne kadar faydalandıklarını ve bu konudaki görüşlerini ortaya koymak amacıyla yaptığı çalışmada, öğrencilerin yarısından fazlasının kendisine ait bilgisayarı olduğu, muhasebe derslerine sınavlarına hazırlanırken teknolojiden faydalandıklarını, derslerde en çok projeksiyon ve akıllı tahta kullanılmasını istediklerini, paket programlardan ise internet tabanlı olanların kullanılmasını istediklerini, tespit etmiştir. Çalışmada ayrıca öğrencilerin teknolojik ders materyali kullanma 
puanlarının cinsiyet, not ortalaması ve muhasebe alanında çalışmayı düşünme durumuna göre anlamlı farklılık göstermediği, fakat teknolojik ders materyali kullanma puanlarının bölüm değişkenine göre anlamlı farklılık gösterdiği tespit edilmiştir.

Güney ve Kaya (2018) teknolojik gelişmelerin muhasebe eğitimi üzerinde etkilerini öğretim elemanları gözünden inceledikleri çalışmada, öğrencilerin mantıksal, zihinsel ve finansal analiz becerilerini ön plana çıkaran ve vergi uygulamalarının, muhasebe işlemlerinin pratik boyutunu kapsayan içeriğe sahip öğrenme tekniklerinin kullanılmasının öğrenmede daha etkin olacağı sonucu ortaya çıkmıştır.

Öztürk ve Erdoğan (2018) muhasebe eğitiminde Prezi kullanımının muhasebe dersi alan öğrenciler üzerinde algı düzeyinin ölçülmesine yönelik bir anket çalışması gerçekleştirmişler ve öğrenciler muhasebe eğitiminde Prezi'nin kullanılması sayesinde muhasebe derslerini daha iyi anladıklarını, kullanılan araç ve gereçten memnun olduklarını ve derslerin daha ilgi çekici ve eğlenceli hale geldiğini ifade etmişlerdir.

\section{4.Öğrencilerin Muhasebe Eğitiminde Teknoloji Kullanımına Bakış Açılarının Tespit Edilmesine Yönelik Araştırma}

Bu bölüm, muhasebe dersi alan öğrencilerin muhasebe eğitiminde teknoloji kullanımına bakış açılarının tespit edilmesine yönelik araştırmanın amacı, yöntemi, araştırmanın bulguları ve yorumlanmasından oluşmaktadır.

\subsection{Araştırmanın Amacı ve Önemi}

Hayatın neredeyse her alanında teknolojik gelişmeler yaşanmakta ve işletmeler de elbette bu gelişmelerden payını almakta ve teknolojiye uyum sağlamak zorunda kalmaktadır. İşletmelerin üretim, AR-GE gibi faaliyetlerinin yanında muhasebe sistemi de teknolojik gelişmelerden etkilenmektedir. Dolayısıyla, geleceğin muhasebe meslek mensubu adaylarının da üniversite eğitimleri esnasında aldıkları muhasebe derslerinde teknoloji kullanımı, iş yaşamına uyum sağlamalarını kolaylaştırabilmektedir. Bu bağlamda çalışmanın amacı, muhasebe dersi alan öğrencilerin muhasebe eğitiminde teknoloji kullanımına yönelik bakış açılarının tespit edilmesidir.

\subsection{Araştırmanın Kapsamı ve Yöntemi}

Çalışmada, muhasebe dersi alan öğrencilerin muhasebe eğitiminde teknoloji kullanımına iliş̧kin bakış açılarının tespit edilmesine yönelik veri toplamak amacıyla anket yöntemi kullanılmıştır. Anket formu, Erol Fidan ve arkadaşları (2015) tarafından yapılan çalışmadan uyarlanarak oluşturulmuştur. Anket öğrencilerin demografik faktörlerinin belirlenmesine ilişkin ve muhasebe eğitiminde teknoloji kullanımına ilişkin bakış açılarının belirlenmesine yönelik olmak üzere iki bölümden oluşmakta ve toplamda 37 sorudan oluşmaktadır. Ankette yer alan sorular beşli Likert ölçeğine (1= kesinlikle katılmıyorum, 2= katılmıyorum, 3= emin değilim, 4= kat1lıyorum, 5= kesinlikle katılıyorum) göre hazırlanmıştır. Elde edilen veriler "SPSS 20.0" istatistiksel paket programı kullanılarak analiz edilmiştir.

Geleceğin muhasebe meslek mensuplarının ve sektörün ihtiyacı olan muhasebe ara elemanı ihtiyacını karşılamak misyonu doğrultusunda eğitim- öğretim hizmeti veren fakültelerde ve meslek yüksekokullarında verilen muhasebe derslerinde teknoloji kullanımı önem teşkil etmektedir. $\mathrm{Bu}$ kapsamda araştırma 2018-2019 eğitim-öğretim yılı bahar yarıyılında Hitit Üniversitesi bünyesindeki fakülte ve meslek yüksekokullarında muhasebe dersi alan öğrenciler üzerinde gerçekleştirilmiştir. Araştırmanın evrenini söz konusu fakülte ve meslek yüksekokulları bünyesinde muhasebe dersi alan İşletme, Maliye, İktisat, Bankacılık ve Finans, İşletme Yönetimi Programı, Muhasebe ve Vergi Uygulamaları Programı, Sağlık Kurumları İşletmeciliği Programı ve Dış Ticaret Programında ders kaydı bulunan toplam 1976 öğrenci oluşturmaktadır. Çalışmada uygulanan anket gün içerisinde eğitim-öğretim hizmeti gören öğrenciler ile gerçekleştirilmiş ve 342 öğrenciye anket uygulanmıştır. 
Çalışmada frekans analizi, faktör analizi ve hipotezlerin test edilmesi amacıyla Mann- Whitney U testi ile Kruskal- Wallis testi yapılmıştır.

\subsection{Araştırmanın Bulguları}

\subsubsection{Güvenilirlik Analizi}

Anket verilerinin değerlendirilmesinde öncelikle güvenilirlik analizi yapılmış, daha sonra ankete katılan öğrencilerin demografik özelliklerinin belirlenmesi amacıyla frekans analizi yapılmış, ankete katılan öğrencilerin verdikleri cevaplar arasında anlamlı bir farklılık olup olmadığının belirlenmesine yönelik ise, Mann Whitney U testi ve Kruskall Wallis testi yapılmıştır.

Anket verilerine öncelikle güvenilirlik testi uygulanmıştır. Güvenilirlik Analizi ile toplam skorların söz konusu olduğu Likert Q tipi vb. ölçeklerin güvenilirliğini belirleyen katsayılar hesaplanmakta ve ölçekte yer alan sorular arasındaki ilişkiler hakkında bilgi elde edilmektedir. Güvenilirlik analizinde kullanılan yöntemlerden birisi olan Alfa Modeli Yönteminde, ölçekte yer alan "k" sorunun homojen bir yapı gösteren bir bütünü ifade edip etmediği araştırılır. Ağırlıklı standart değişim ortalamasıdır ve bir ölçekteki " $k$ " sorunun varyansları toplamının genel varyansa oranlanması ile elde edilir. O ile 1 arasında değer alan bu katsayı (Cronbach) Alfa katsayısı olarak adlandırılır. $\mathrm{Bu}$ katsayının 1'e yakın değer alması ölçeğin güvenilir olduğunu göstermektedir (Kalayc1, 2010: 403, 405).

Tablo 1: Güvenilirlik Analizi

\begin{tabular}{|c|c|}
\hline Cronbach's Alpha & N of Items \\
\hline, 735 & 51 \\
\hline
\end{tabular}

Güvenilirlik testi sonucunda, muhasebe dersi alan ön lisans öğrencilerinin yeşil muhasebe hakkındaki farkındalıklarının ve bakış açılarının tespit edilmesine yönelik geliştirilen ölçeğin genel Cronbach's Alpha katsayısı 0,735 düzeyinde anlamlı bulunmuştur. Bu sonuca göre ölçeğin oldukça güvenilir olduğu tespit edilmiştir.

\subsubsection{Frekans Analizi}

Muhasebe dersi alan öğrencilerin muhasebe derslerinde teknoloji kullanımına ilişkin bakış açılarının tespit edilmesine yönelik yapılan ankete katılan öğrencilerin demografik özelliklerinin belirlenmesine yönelik frekans analizi yapılmıştır.

Tablo 2: Ankete Katılan Öğrencilerin Demografik Özelliklerine Yönelik Frekans Dağılımı

\begin{tabular}{|c|c|c|c|c|c|c|c|}
\hline & & Frekans & Yüzde & & & Frekans & Yüzde \\
\hline \multirow[b]{2}{*}{ Cinsiyet } & Kadın & 209 & 61,1 & \multirow[t]{2}{*}{ Öğrenim Türü } & Normal öğretim & 272 & 79,5 \\
\hline & Erkek & 133 & 38,9 & & İkinci Öğretim & 70 & 20,5 \\
\hline \multirow{4}{*}{ Yaş } & $17-23$ & 275 & 80,4 & \multirow{4}{*}{ Ortalama } & 1,99 ve alt1 & 29 & 8,5 \\
\hline & $24-30$ & 64 & 18,7 & & 2,00 ve 2,99 aras 1 & 244 & 71,3 \\
\hline & \multirow[t]{2}{*}{31 yaş ve üzeri } & \multirow[b]{2}{*}{3} & \multirow{2}{*}{,9 } & & 3,00 ve üzeri & 65 & 19,0 \\
\hline & & & & & Cevap vermeyen & 4 & 1,2 \\
\hline \multirow[b]{4}{*}{ Bölüm } & $\begin{array}{l}\text { İşletme Yönetimi } \\
\text { (MYO) }\end{array}$ & 39 & 11,4 & \multirow[b]{4}{*}{ Sinıf } & Birinci Sınıf & 62 & 18,1 \\
\hline & Diş Ticaret (MYO) & 2 & ,6 & & İkinci Sınıf & 45 & 13,2 \\
\hline & $\begin{array}{l}\text { Sağlık Kurumları } \\
\text { İşletmeciliği (NÖ) }\end{array}$ & 34 & 9,9 & & Üçüncü Sınıf & 81 & 23,7 \\
\hline & $\begin{array}{l}\text { Muhasebe ve vergi } \\
\text { Uygulamaları } \\
\text { (MYO) }\end{array}$ & 34 & 9,9 & & $\begin{array}{l}\text { Dördüncü } \\
\text { Sinıf }\end{array}$ & 154 & 45,0 \\
\hline
\end{tabular}




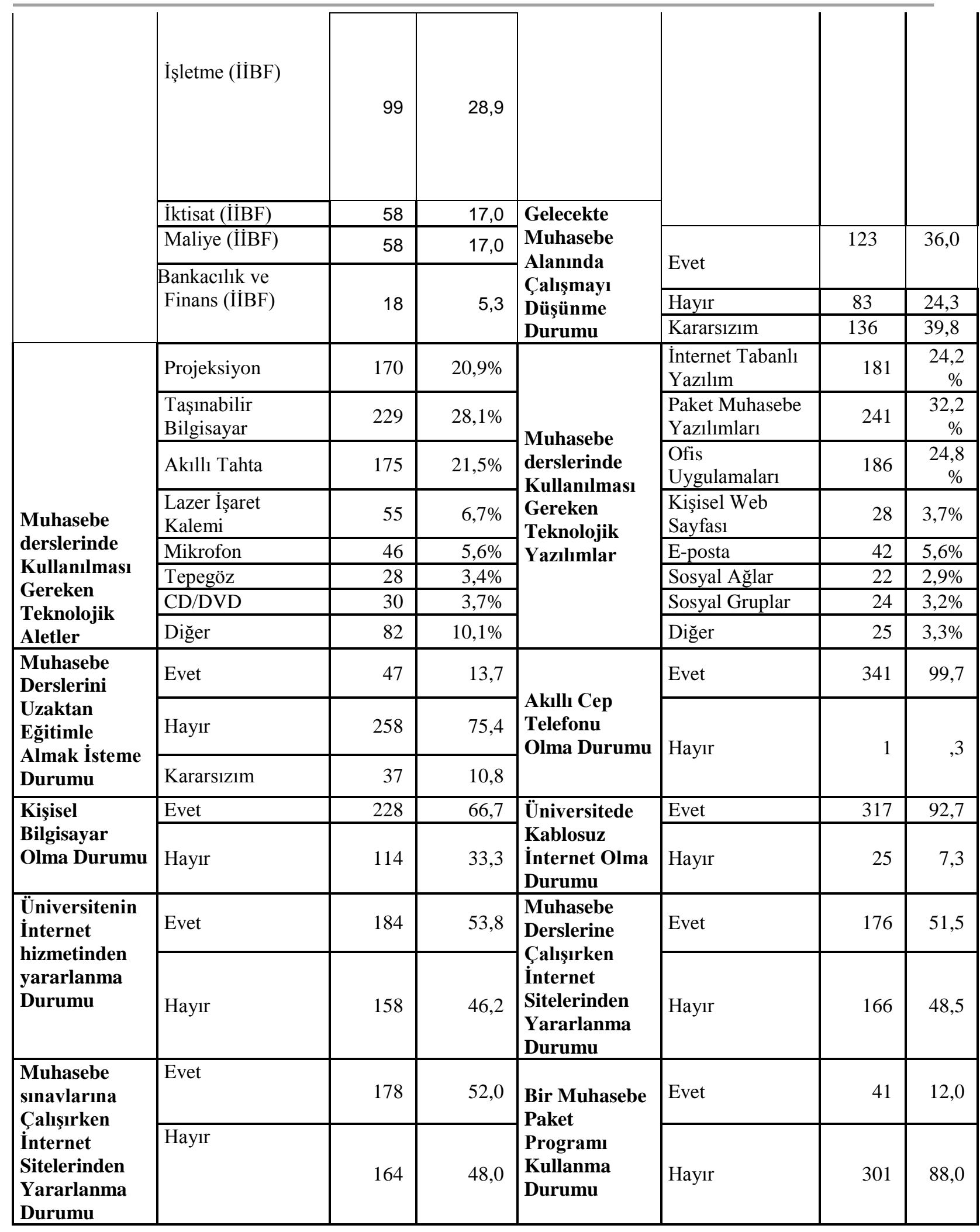

Ankete katılan öğrencilerin demografik özelliklerine bakıldığında çoğunluğun k1z öğrencilerden oluştuğu ve 17-23 yaş arası öğrencilerin çoğunlukta olduğu görülmektedir. Öğrencilerin 
not ortalamalarının çoğunlukla 2,00 ve 2,99 arasında olduğu, bölüm olarak işletme, iktisat, maliye lisans bölümünde olmaları ve çoğunluğun dördüncü sınıf olmaları da bir başka bulgudur. Gelecekte muhasebe alanında çalışma konusundaki görüşlere bakıldığında sonuçların birbirine yakın olduğu görülmektedir. Öğrencilerin büyük çoğunluğu muhasebe derslerini uzaktan eğitim yöntemiyle almak istemediklerini belirtmişlerdir. Ankete katılan öğrencilerin derslerde kullanılması gereken teknolojik aletler konusundaki görüşlerine bakıldığında, öğrenciler daha çok taşınabilir bilgisayar, projeksiyon cihazı ve akıllı tahta kullanılması gerektiğini belirtmişler, aynı şekilde teknolojik yazılımlardan ise, paket muhasebe yazılımları, ofis uygulamaları ve internet tabanlı yazılımların kullanılması gerektiğini belirtmişlerdir.

Katılımcıların \%99'unun akıllı cep telefonlarının bulunduğu ve \%67'sinin ise kişisel bilgisayara sahip oldukları görülmektedir. Öğrencilerin büyük çoğunluğu üniversitelerinde kablosuz internet hizmeti bulunduğunu belirtmişler ancak, bu hizmetten yararlanma durumları açısından bakıldığında evet diyenlerle hayır diyenlerin oranının birbirine yakın olduğu görülmektedir. Ankete katılan öğrencilerin muhasebe derslerine ve sınavlarına çalışırken internet sitelerinden yararlanıp yararlanmadıkları sorulmuş ve sonuçlar birbirine oldukça yakın gerçekleşmiştir. Ayrıca öğrencilerin büyük çoğunluğu bir muhasebe paket programı kullanmadıklarını belirtmişlerdir.

Tablo 3: Ankete Katılan Öğrencilerin Muhasebe Derslerinde Teknoloji Kullanımına İlişkin Bakış Açılarına Yönelik Frekans Dağılımı

\begin{tabular}{|c|c|c|c|c|c|c|c|c|}
\hline İfadeler & Ortalama & $\begin{array}{l}\text { Standart } \\
\text { Sapma }\end{array}$ & $\mathbf{F}$ & 1 & 2 & 3 & 4 & 5 \\
\hline \multirow{2}{*}{$\begin{array}{l}\text { 18. Teknolojik ürünlerin (powerpoint } \\
\text { sunum, bilgisayar, ak1ll tahta, } \\
\text { muhasebe paket programları vb.) } \\
\text { kullanım muhasebe derslerini keyifli } \\
\text { hale getirir. }\end{array}$} & \multirow[b]{2}{*}{8450} & \multirow[b]{2}{*}{25699} & $\mathrm{~F}$ & 36 & 16 & 36 & 131 & 123 \\
\hline & & & $\%$ & $\begin{array}{c}10 \\
5\end{array}$ & 4,7 & 10,5 & 38,3 & 36,0 \\
\hline \multirow{2}{*}{$\begin{array}{l}\text { 19.Teknolojik ürünlerin kullanımı } \\
\text { sayesinde muhasebe dersleri daha } \\
\text { kolay anlaşı1ır. }\end{array}$} & \multirow[b]{2}{*}{8918} & \multirow[b]{2}{*}{18767} & $\mathrm{~F}$ & 27 & 21 & 36 & 136 & 122 \\
\hline & & & $\%$ & 7,9 & 6,1 & 10,5 & 39,8 & 35,7 \\
\hline \multirow{2}{*}{$\begin{array}{l}\text { 20.Teknolojik ürünlerin kullanım1 } \\
\text { sayesinde muhasebe derslerine olan } \\
\text { ilgi artar. }\end{array}$} & \multirow[b]{2}{*}{3,8538} & \multirow[b]{2}{*}{1,15219} & F & 23 & 23 & 48 & 135 & 113 \\
\hline & & & $\%$ & 6,7 & 6,7 & 14,0 & 39,5 & 33,0 \\
\hline \multirow{2}{*}{$\begin{array}{l}\text { 21.Teknolojik ürünlerin kullanımı } \\
\text { muhasebe derslerinde başarıı arttırır. }\end{array}$} & \multirow{2}{*}{3,76} & \multirow{2}{*}{1,17811} & $\mathrm{~F}$ & 25 & 22 & 70 & 116 & 109 \\
\hline & & & $\%$ & 3 & 4 & 20,5 & 33,9 & 31,9 \\
\hline \multirow{2}{*}{$\begin{array}{l}\text { 22.Teknolojik ürünlerin kullanımı } \\
\text { muhasebeyi sevmeyi sağlar. }\end{array}$} & \multirow{2}{*}{3,6520} & \multirow{2}{*}{1,16346} & $\mathrm{~F}$ & 25 & 29 & 74 & 126 & 88 \\
\hline & & & $\%$ & 7,3 &, 5 & 21,6 & 36,8 & 25,7 \\
\hline \multirow{2}{*}{$\begin{array}{l}\text { 23.Teknolojik ürünlerin kullanımı } \\
\text { sayesinde dersleri takip etmek } \\
\text { kolaylaşır. }\end{array}$} & \multirow[b]{2}{*}{3,903} & \multirow[b]{2}{*}{5869} & 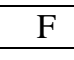 & 25 & 22 & 31 & 147 & 117 \\
\hline & & & $\%$ & 7,3 & 6,4 & 9,1 & 43,0 & 34,2 \\
\hline \multirow{2}{*}{$\begin{array}{l}\text { 24.Teknolojik ürünlerin kullanımı } \\
\text { sayesinde derslerde not almak daha } \\
\text { kolay olur. }\end{array}$} & & & $\mathrm{F}$ & 25 & 18 & 59 & 126 & 114 \\
\hline & & & $\%$ & 7,3 & 5,3 & 17,3 & 36,8 & 33,3 \\
\hline \multirow{2}{*}{$\begin{array}{l}\text { 25.Teknolojik ürünlerin kullanımı } \\
\text { sayesinde derslerin akılda kalıcı } \\
\text { olması kolaylasır. }\end{array}$} & \multirow[b]{2}{*}{3,7982} & \multirow[b]{2}{*}{1,18777} & $\mathrm{~F}$ & 27 & 23 & 51 & 132 & 109 \\
\hline & & & $\%$ & 7,9 & 6,7 & 14,9 & 38,6 & 31,9 \\
\hline \multirow{2}{*}{$\begin{array}{l}\text { 26.Teknolojik ürünlerin kullanımı } \\
\text { derslere aktif katılım düzeyini artırır. }\end{array}$} & \multirow{2}{*}{3,7398} & \multirow{2}{*}{1,13054} & $\mathrm{~F}$ & 21 & 24 & 76 & 123 & 98 \\
\hline & & & $\%$ & 61 & 7. & 22,2 & 36,0 & 28,7 \\
\hline \multirow{2}{*}{$\begin{array}{l}\text { 27.Teknolojik ürünlerin kullanımı ile } \\
\text { derslerde daha fazla pratik yapılabilir. }\end{array}$} & \multirow{2}{*}{3,8684} & \multirow{2}{*}{1,16785} & $\mathrm{~F}$ & 25 & 21 & 45 & 134 & 117 \\
\hline & & & $\%$ & 7,3 & 6,1 & 13,2 & 39,2 & 34,2 \\
\hline \multirow{2}{*}{$\begin{array}{l}\text { 28.Teknolojik ürünlerin kullanımında } \\
\text { eğitici ile iletişim kurmak zorlaşır. }\end{array}$} & \multirow{2}{*}{2,6754} & \multirow{2}{*}{1,32312} & $\mathrm{~F}$ & 78 & 94 & 75 & 51 & 44 \\
\hline & & & $\%$ & 22,8 & 27,5 & 21,9 & 14,9 & 12,9 \\
\hline
\end{tabular}




\begin{tabular}{|c|c|c|c|c|c|c|c|c|}
\hline \multirow{2}{*}{$\begin{array}{l}\text { 29.Teknolojik ürünlerin kullanımı } \\
\text { öğrencilerin dalgın olmasına neden } \\
\text { olur. }\end{array}$} & \multirow[b]{2}{*}{2,6345} & \multirow[b]{2}{*}{1,25059} & $\mathrm{~F}$ & 71 & 103 & 84 & 48 & 36 \\
\hline & & & $\%$ & 20,8 & 30,1 & 24,6 & 14,0 & 10,5 \\
\hline \multirow{2}{*}{$\begin{array}{l}\text { 30.Muhasebe derslerine giren öğretim } \\
\text { üyeleri eğitimle ilgili güncel } \\
\text { teknolojileri takip etmelidir. }\end{array}$} & \multirow[b]{2}{*}{3,9035} & \multirow[b]{2}{*}{1,15362} & $\Gamma$ & 21 & 24 & 47 & 125 & 125 \\
\hline & & & $\%$ & 6,1 & 7,0 & 13,7 & 36,5 & 36,5 \\
\hline \multirow{2}{*}{$\begin{array}{l}\text { 31.Sınıfta muhasebe dersleri } \\
\text { anlatıldıktan sonra konu ile ilgili ders } \\
\text { notları internet ortamında da } \\
\text { paylaşılmalıdır. }\end{array}$} & \multirow[b]{2}{*}{3,9381} & \multirow[b]{2}{*}{1,18134} & $\mathrm{~F}$ & 23 & 22 & 43 & 116 & 135 \\
\hline & & & $\%$ & 6,7 & 6,4 & 12,6 & 33,9 & 39,5 \\
\hline \multirow{2}{*}{$\begin{array}{lrr}32 . \text { Muhasebe } & \text { dersleri } & \text { teknolojik } \\
\text { ürünlerin bulunduğu } & \text { sinıflarda } \\
\text { anlatılmalıdır. } & \end{array}$} & \multirow[b]{2}{*}{3,8626} & \multirow[b]{2}{*}{1,16214} & $\mathrm{~F}$ & 23 & 22 & 53 & 125 & 119 \\
\hline & & & $\%$ & 6,7 & 6,4 & 15,5 & 36,5 & 34,8 \\
\hline \multirow{2}{*}{$\begin{array}{l}\text { 33.Muhasebe paket programları } \\
\text { ayrıca bir ders olarak verilmelidir. }\end{array}$} & \multirow{2}{*}{3,9444} & \multirow{2}{*}{1,16391} & & 22 & 21 & $\pi$ & 118 & 135 \\
\hline & & & & 6,4 & 0,1 & 13,5 & 4,5 & 39,5 \\
\hline \multirow{2}{*}{$\begin{array}{l}\text { 34.Muhasebe derslerinde klasik } \\
\text { yöntem değil powerpoint programları } \\
\text { kullanılmalıdır. }\end{array}$} & \multirow[b]{2}{*}{3,5380} & \multirow[b]{2}{*}{1,22176} & & 26 & 4 & 82 & 100 & 90 \\
\hline & & & $\%$ & 7,6 & 12,9 & 24,0 & 29,2 & 26,3 \\
\hline \multirow{2}{*}{$\begin{array}{l}\text { 35.Muhasebe derslerinde internet } \\
\text { tabanlı oyun yöntemi kullanılması } \\
\text { muhasebenin daha iyi anlaşılmasını } \\
\text { sağlar. }\end{array}$} & \multirow[b]{2}{*}{3,5351} & \multirow[b]{2}{*}{1,26662} & & 33 & 37 & 81 & 96 & 95 \\
\hline & & & $\%$ & 9,6 & 10,8 & 23,7 & 28,1 & 27,8 \\
\hline \multirow{2}{*}{$\begin{array}{l}\text { 36.Muhasebe sınavlarında internet } \\
\text { tabanlı oyun yöntemi kullanılması } \\
\text { başarıyı artırır. }\end{array}$} & \multirow[b]{2}{*}{3,5058} & \multirow[b]{2}{*}{1,29003} & & 32 & 35 & 92 & 100 & 82 \\
\hline & & & $\%$ & 9,4 & 10,2 & 26,9 & 29,2 & 24,0 \\
\hline \multirow{2}{*}{$\begin{array}{lcr}\text { 37.Temel } & \text { muhasebe } & \text { konuları } \\
\text { anlat1lırken } & \text { teknolojik } & \text { ürün } \\
\text { kullanılması faydalı değildir. } & \end{array}$} & \multirow[b]{2}{*}{2,5585} & \multirow[b]{2}{*}{1,42899} & & 104 & 93 & 4 & 46 & 52 \\
\hline & & & $\%$ & 30,4 & 27,2 & 13,7 & 13,5 & 15,2 \\
\hline
\end{tabular}

Muhasebe dersi alan öğrencilerin, anketin ikinci kısmındaki muhasebe derslerinde teknoloji kullanımı ile ilgili 20 ifadeye verdikleri yanıtların frekans analizi sonuçları Tablo 3'de sunulmuştur. Tablo 3'e göre öğrencilerin 3,9444 ortalama ile en çok "muhasebe paket programları ayrıca bir ders olarak verilmelidir" ifadesine katıldıkları görülmüştür. Bunu 3,9381 ortalama ile "Sınıfta muhasebe dersleri anlatıldıktan sonra konu ile ilgili ders notları internet ortamında da paylaşılmalıdır" ifadesi takip etmektedir. 3,9035 ortalama ile "muhasebe dersleri veren öğretim üyeleri eğitimle ilgili yeni teknolojileri takip etmelidir" ifadesi ile yine aynı ortalama ile "teknolojik ürünlerin kullanımı ile dersleri takip etmek daha kolay olur" ifadelerinin en çok önem verilen ifadeler olduğu görülmektedir.

\subsubsection{Faktör Analizi}

Bir çalışmada kullanılan ölçeğin faktör analizine uygun olup olmadığını test etmek amacıyla kullanılan yöntemlerden birisi de "Kaiser- Meyer- Olkin (KMO) örneklem yeterliliği ölçütü" yöntemidir. Yönteme göre KMO oranının $(0,5)$ 'in üzerinde olması gerekmektedir. Bu oranın yüksek olması çalışmanın faktör analizi yapmak için uygun olduğu anlamına gelmektedir (Kalayc1, 2010: 321, 322).

Çalışmada kullanılan veri seti, faktör analizine uygunluk açısından test edilmiş ve KaiserMeyer- Olkin (KMO) değeri 0, 944 bulunmuştur. Buradan anket sorularının faktör analizine uygun olduğu sonucuna ulaşılmış ve yapılan direct oblimin rotasyonlu faktör analizi sonucunda 3 faktör belirlenmiştir. Faktör analizi sonuçları Tablo 4'de belirtilmiştir. 
Tablo 4: Açımlayıcı Faktör Analizi Sonuçları

\begin{tabular}{|c|c|c|c|}
\hline & F1 & F2 & F3 \\
\hline \multicolumn{4}{|l|}{ Faktör 1: Muhasebe Derslerinde Teknoloji Kullanımı Algısı } \\
\hline $\begin{array}{l}\text { Teknolojik ürünlerin (powerpoint sunum, bilgisayar, akıllı tahta, muhasebe paket } \\
\text { programları vb.) kullanımı muhasebe derslerini keyifli hale getirir. (s.18) }\end{array}$ & ,799 & & \\
\hline $\begin{array}{l}\text { Teknolojik ürünlerin kullanımı sayesinde muhasebe dersleri daha kolay anlaşılır. } \\
\text { (s.19) }\end{array}$ & ,799 & & \\
\hline Teknolojik ürünlerin kullanımı sayesinde muhasebe derslerine olan ilgi artar. (s.20) & ,813 & & \\
\hline Teknolojik ürünlerin kullanımı muhasebe derslerinde başarıyı arttırır. (s.21) & 837 & & \\
\hline Teknolojik ürünlerin kullanımı muhasebeyi sevmeyi sağlar. (s.22) &, 835 & & \\
\hline Teknolojik ürünlerin kullanımı sayesinde dersleri takip etmek kolaylaşır. (s.23) & ,933 & & \\
\hline Teknolojik ürünlerin kullanımı sayesinde derslerde not almak daha kolay olur. (s.24) & 873 & & \\
\hline $\begin{array}{l}\text { Teknolojik ürünlerin kullanımı sayesinde derslerin akılda kalıcı olması kolaylaşır. } \\
\text { (s.25) }\end{array}$ & ,859 & & \\
\hline Teknolojik ürünlerin kullanımı derslere aktif katılım düzeyini artırır. (s.26) &, 813 & & \\
\hline Teknolojik ürünlerin kullanımı ile derslerde daha fazla pratik yapılabilir. (s.27) & 832 & & \\
\hline $\begin{array}{l}\text { Muhasebe derslerine giren öğretim üyeleri eğitimle ilgili güncel teknolojileri takip } \\
\text { etmelidir. (s.30) }\end{array}$ &, 586 & & \\
\hline $\begin{array}{l}\text { Sınıfta muhasebe dersleri anlatıldıktan sonra konu ile ilgili ders notları internet } \\
\text { ortamında da paylaşılmalıdır. (s.31) }\end{array}$ & ,468 & & \\
\hline Muhasebe dersleri teknolojik ürünlerin bulunduğu sınıflarda anlatılmalıdır. (s.32) &, 530 & & \\
\hline Faktör 2: Teknoloji Kullanımı İle İlgili Olumsuz Algı & & \multirow{2}{*}{, 889} & \\
\hline Teknolojik ürünlerin kullanımında eğitici ile iletişim kurmak zorlaşır. (s.28) & & & \\
\hline Teknolojik ürünlerin kullanımı öğrencilerin dalgın olmasına neden olur. (s.29) & & ,854 & \\
\hline $\begin{array}{l}\text { Temel muhasebe konuları anlatılırken teknolojik ürün kullanılması faydalı değildir. } \\
\text { (s.37) }\end{array}$ & &, 585 & \\
\hline Faktör 3: Muhasebe Derslerinde Teknolojiye Dayalı Anlatım & & & \multirow{2}{*}{,- 514} \\
\hline Muhasebe paket programları ayrıca bir ders olarak verilmelidir. (s.33) & & & \\
\hline $\begin{array}{l}\text { Muhasebe derslerinde klasik yöntem değil powerpoint programları kullanılmalıdır. } \\
\text { (s.34) }\end{array}$ & & &,- 613 \\
\hline $\begin{array}{l}\text { Muhasebe derslerinde internet tabanlı oyun yöntemi kullanılması muhasebenin } \\
\text { daha iyi anlaşılmasını sağlar. (s.35) }\end{array}$ & & &,- 804 \\
\hline $\begin{array}{l}\text { Muhasebe sınavlarında internet tabanlı oyun yöntemi kullanılması başarıyı artırı } \\
\text { (s.36) }\end{array}$ & & &,- 843 \\
\hline
\end{tabular}

Not: 0,30 atındaki değerler gösterilmemiştir.

Yapılan faktör analizi sonucuna göre faktörlerin varyansları açıklama yüzdeleri Tablo 5'de belirtilmiştir. Tabloya göre faktörlerin toplam varyansı açıklama yüzdesi $\% 66,435$ 'dir. Varyansı açıklama yüzdesi en yüksek olan faktör \% 9,938 değeri ile" muhasebe derslerinde teknoloji kullanımı algısı" faktörüdür. Bunu sırasıyla "teknoloji kullanımı ile ilgili olumsuz algı" faktörü ve "muhasebe derslerinde teknolojiye dayalı anlatım" faktörü izlemektedir. 
Tablo 5: Faktörlerin Varyansı Açıklama Yüzdeleri

\begin{tabular}{|c|c|c|c|}
\hline \multicolumn{3}{|c|}{ Total Variance Explained } \\
\hline Component & \multicolumn{3}{|c|}{ Extraction Sums of Squared Loadings } \\
\cline { 2 - 4 } & Total & \% of Variance & Cumulative \% \\
\hline F1 & 9,938 & 49,688 & 49,688 \\
\hline F2 & 2,050 & 10,249 & 59,937 \\
\hline F3 & 1,300 & 6,498 & 66,435 \\
\hline
\end{tabular}

\subsubsection{Hipotez Testleri}

Ankete katılan öğrencilerin muhasebe derslerinde teknoloji kullanımı ile ilgili algıları ile cinsiyet, kaçıncı sınıfta oldukları, ortalamaları, bölümleri, gelecekte muhasebe alanında çalışmayı düşünme durumları, muhasebe derslerini uzaktan eğitim yöntemiyle almak isteme durumları, kişisel bilgisayara sahip olma durumu, muhasebe dersleri ile sınavlarına çalışırken internet sitelerinden yararlanma durumu ve bir muhasebe paket programı kullanıp kullanmama durumu arasinda anlamlı bir farklılık olup olmadığ 1 test edilmiştir. Hipotez testi yapılmadan önce veri setinin normal dağılımdan gelip gelmediği test edilmiştir.

Bir çalışmada parametrik analiz yapılabilmesi için verilerin aralıklı ya da oransal olması, kolmogorov- smirnov değerinin 0.05 'den büyük olması, basıklık ve çarpıklık değerlerinin -1 ve +1 arasında olması ve grup varyanslarının eşit olması gerekmektedir (Kalaycı, 2010: 73). Çalışmanın verileri parametrik analiz varsayımlarını taşımadığı için hipotezlerin test edilmesi için non- parametrik testlerden Mann- Whitney U testi ile Kruskal- Wallis testi yapılmıştır. Bu kapsamda çalışmanın hipotezleri aşağıda belirtildiği gibidir.

\section{Öğrencilerin cinsiyetleri ile muhasebe derslerinde teknoloji kullanımına ilişkin bakış açıları arasındaki durum:}

Öğrencilerin muhasebe derslerinde teknoloji kullanımına yönelik bakış açıları ile cinsiyet değişkenine ilişkin Mann- Whitney U testi sonuçları Tablo 6'da gösterilmiştir.

Tablo 6: Öğrencilerin muhasebe derslerinde teknoloji kullanımına yönelik bakış açıları ile cinsiyet değişkenine ilişkin Mann- Whitney U testi sonuçları

\begin{tabular}{|c|c|c|c|c|c|c|c|}
\hline & Cinsiyet & $\mathbf{N}$ & $\begin{array}{c}\text { Sira } \\
\text { Ortalaması }\end{array}$ & $\begin{array}{c}\text { Sira } \\
\text { Toplamı }\end{array}$ & $\mathbf{U}$ & $\mathbf{Z}$ & $\mathbf{P}$ \\
\hline $\begin{array}{l}\text { Faktör 1: Muhasebe } \\
\text { Derslerinde }\end{array}$ & Kadın & 209 & 173,10 & 36178,00 & \multirow[t]{2}{*}{13564,000} & \multirow[t]{2}{*}{,- 376} & \multirow[t]{2}{*}{,707 } \\
\hline $\begin{array}{l}\text { Teknoloji Kullanımı } \\
\text { Algisı }\end{array}$ & Erkek & 133 & 168,98 & 22475,00 & & & \\
\hline Faktör 2: Teknoloji & Kadın & 209 & 169,71 & 23184,00 & \multirow[t]{2}{*}{13524,000} & \multirow[t]{2}{*}{,- 422} & \multirow[t]{2}{*}{,673 } \\
\hline Olumsuz Alg1 & Erkek & 133 & 174,32 & 51398,5 & & & \\
\hline $\begin{array}{l}\text { Faktör 3: Muhasebe } \\
\text { Derslerinde }\end{array}$ & Kadın & 209 & 174,47 & 36464,50 & \multirow[t]{2}{*}{13277,500} & \multirow[t]{2}{*}{,- 700} & \multirow[t]{2}{*}{,484 } \\
\hline $\begin{array}{l}\text { Teknolojiye Dayalı } \\
\text { Anlatım }\end{array}$ & Erkek & 133 & 166,83 & 22188,50 & & & \\
\hline
\end{tabular}

Tablo 6'da gösterilen Mann-Whitney U testi sonuçlarına göre, öğrencilerin muhasebe derslerinde teknoloji kullanımına ilişkin bakış açıları ile cinsiyet değişkeni arasında anlamlı bir fark 
bulunmamıştır. Yani öğrencilerin muhasebe derslerinde teknoloji kullanılmasına yönelik algıları kız öğrenciler ve erkek öğrenciler açısından bir farklılık göstermemektedir. $(\mathrm{p}<0,05)$.

\section{Öğrencilerin sınıfları ile muhasebe derslerinde teknoloji kullanımına ilişkin bakış açıları arasındaki durum:}

Öğrencilerin muhasebe derslerinde teknoloji kullanımına ilişkin bakış açıları ile sınıf değişkenine ait Kruskal- Wallis testi sonuçları Tablo 7'de gösterilmiştir.

Tablo 7: Öğrencilerin muhasebe derslerinde teknoloji kullanımına yönelik bakış açıları ile sınıf değişkenine ilişkin Kruskal- Wallis testi sonuçları

\begin{tabular}{|c|c|c|c|c|c|}
\hline & Sinıf & $\mathbf{N}$ & $\begin{array}{c}\text { Sira } \\
\text { Ortalaması }\end{array}$ & $\begin{array}{l}\text { Chi- } \\
\text { Square }\end{array}$ & $\mathbf{P}$ \\
\hline \multirow{4}{*}{$\begin{array}{l}\text { Faktör 1: Muhasebe Derslerinde } \\
\text { Teknoloji Kullanımı Algis1 }\end{array}$} & Birinci Sinıf & 62 & 136,44 & \multirow{4}{*}{26,797} & \multirow{4}{*}{,000 } \\
\hline & İkinci Sınıf & 45 & 128,59 & & \\
\hline & Üçüncü Sınıf & 81 & 173,22 & & \\
\hline & Dördüncü Sınıf & 154 & 197,25 & & \\
\hline \multirow{4}{*}{$\begin{array}{l}\text { Faktör 2: Teknoloji Kullanımı İle İlgili } \\
\text { Olumsuz Algı }\end{array}$} & Birinci Sinıf & 62 & 196,96 & \multirow{4}{*}{6,440} & \multirow{4}{*}{,092 } \\
\hline & İkinci Sınıf & 45 & 173,32 & & \\
\hline & Üçüncü Sinıf & 81 & 173,52 & & \\
\hline & Dördüncü Sınıf & 154 & 159,65 & & \\
\hline \multirow{4}{*}{$\begin{array}{l}\text { Faktör 3: Muhasebe Derslerinde } \\
\text { Teknolojiye Dayalı Anlatım }\end{array}$} & Birinci Sınıf & 62 & 146,40 & \multirow{4}{*}{15,440} & \multirow{4}{*}{,001 } \\
\hline & İkinci Sınıf & 45 & 146,58 & & \\
\hline & Üçüncü Sinıf & 81 & 162,36 & & \\
\hline & Dördüncü Sınıf & 154 & 193,69 & & \\
\hline
\end{tabular}

Tablo 7'de gösterilen Kruskal- Wallis testi sonuçlarına göre öğrencilerin muhasebe derslerinde teknoloji kullanımı algısı faktörü ve muhasebe derslerinde teknolojiye dayalı anlatım faktörü ile ögrencilerin sınıfları arasında anlamlı bir fark bulunmuş $(p<0,05)$, ancak muhasebe derslerinde teknoloji kullanımı ile ilgili olumsuz algı faktörü arasında anlamlı bir fark bulunmamıştır $(p<0,05)$.

Öğrencilerin ortalamaları ile muhasebe derslerinde teknoloji kullanımına ilişkin bakış açıları arasındaki durum:

Öğrencilerin muhasebe derslerinde teknoloji kullanımına ilişkin bakış açıları ile ortalama değişkenine ait Kruskal- Wallis testi sonuçları Tablo 8'de gösterilmiştir.

Tablo 8: Öğrencilerin muhasebe derslerinde teknoloji kullanımına yönelik bakış açıları ile ortalama değişkenine ilişskin Kruskal- Wallis testi sonuçları

\begin{tabular}{|c|c|c|c|c|c|}
\hline & Ortalama & $\mathbf{N}$ & $\begin{array}{c}\text { Sira } \\
\text { Ortalaması }\end{array}$ & $\begin{array}{c}\text { Chi- } \\
\text { Square }\end{array}$ & $\mathbf{P}$ \\
\hline \multirow{3}{*}{$\begin{array}{l}\text { Faktör 1: Muhasebe } \\
\text { Derslerinde Teknoloji } \\
\text { Kullanımı Algis1 }\end{array}$} & 1,99 ve altı ortalama & 29 & 158,81 & \multirow{3}{*}{1,372} & \multirow{3}{*}{, 504} \\
\hline & $2,00-2,99$ aras 1 ortalama & 244 & 167,65 & & \\
\hline & 3,00 ve üzeri ortalama & 65 & 181,22 & & \\
\hline \multirow{3}{*}{$\begin{array}{l}\text { Faktör 2: Teknoloji } \\
\text { Kullanımı İle İlgili } \\
\text { Olumsuz Alg1 }\end{array}$} & 1,99 ve altı ortalama & 29 & 189,84 & \multirow[b]{3}{*}{1,445} & \multirow[b]{3}{*}{,485 } \\
\hline & $2,00-2,99$ aras1 ortalama & 244 & 166,92 & & \\
\hline & 3,00 ve üzeri ortalama & 65 & 170,12 & & \\
\hline \multirow{3}{*}{$\begin{array}{l}\text { Faktör 3: Muhasebe } \\
\text { Derslerinde Teknolojiye } \\
\text { Dayalı Anlatım }\end{array}$} & 1,99 ve altı ortalama & 29 & 189,02 & \multirow{3}{*}{6,202} & \multirow{3}{*}{, 045} \\
\hline & $2,00-2,99$ aras1 ortalama & 244 & 161,33 & & \\
\hline & 3,00 ve üzeri ortalama & 65 & 191,47 & & \\
\hline
\end{tabular}


Tablo 8'de gösterilen Kruskal- Wallis testi sonuçlarına göre öğrencilerin muhasebe derslerinde teknoloji kullanımı algısı faktörü ve muhasebe derslerinde teknoloji kullanımı ile ilgili olumsuz alg1 faktörü ile öğrencilerin ortalamaları arasında anlamlı bir fark tespit edilmemiş $(p<0,05)$, ancak muhasebe derslerinde teknolojiye dayalı anlatım faktörü ile öğrencilerin ortalamaları arasında anlamlı bir fark tespit edilmiştir $(\mathrm{p}<0,05)$.

\section{Öğrencilerin bölümleri ile muhasebe derslerinde teknoloji kullanımına ilişkin bakış açıları arasındaki durum:}

Öğrencilerin muhasebe derslerinde teknoloji kullanımına ilişkin bakış açıları ile bölüm değişkenine ait Kruskal- Wallis testi sonuçları Tablo 9'da gösterilmiştir.

Tablo 9: Öğrencilerin muhasebe derslerinde teknoloji kullanımına yönelik bakış açıları ile bölüm değişkenine iliş̧kin Kruskal- Wallis testi sonuçları

\begin{tabular}{|c|c|c|c|c|c|}
\hline & Bölüim & $\mathbf{N}$ & $\begin{array}{c}\text { Sira } \\
\text { Ortalamasi }\end{array}$ & $\begin{array}{l}\text { Chi- } \\
\text { Square }\end{array}$ & $\mathbf{P}$ \\
\hline \multirow{8}{*}{$\begin{array}{l}\text { Faktör 1: Muhasebe } \\
\text { Derslerinde Teknoloji } \\
\text { Kullanımı Algıs1 }\end{array}$} & İşletme Yönetimi (MYO & 39 & 136,15 & \multirow{8}{*}{26,797} & \multirow{8}{*}{,000 } \\
\hline & D1ş Ticaret (MYO) & 2 & 144,50 & & \\
\hline & $\begin{array}{c}\text { Sağlık Kurumları } \\
\text { İşletmeciliği (MYO) }\end{array}$ & 34 & 143,13 & & \\
\hline & $\begin{array}{l}\text { Muhasebe ve vergi } \\
\text { Uygulamaları (MYO) }\end{array}$ & 34 & 129,66 & & \\
\hline & İşletme (İ̈BF) & 99 & 196,74 & & \\
\hline & İktisat (İ̈BF) & 58 & 170,20 & & \\
\hline & Maliye (İ̈BF) & 58 & 177,83 & & \\
\hline & Bankacılık ve Finans (İ̈BF) & 18 & 228,67 & & \\
\hline \multirow{8}{*}{$\begin{array}{l}\text { Faktör 2: Teknoloji } \\
\text { Kullanımı İle İlgili } \\
\text { Olumsuz Alg1 }\end{array}$} & İşletme Yönetimi (MYO & 39 & 182,33 & \multirow{8}{*}{6,936} & \multirow{8}{*}{,436 } \\
\hline & Dış Ticaret (MYO) & 2 & 160,00 & & \\
\hline & $\begin{array}{l}\text { Sağlık Kurumları } \\
\text { İşletmeciliği (MYO) }\end{array}$ & 34 & 173,97 & & \\
\hline & $\begin{array}{c}\text { Muhasebe ve vergi } \\
\text { Uygulamaları (MYO) }\end{array}$ & 34 & 202,93 & & \\
\hline & İşletme (İ̈BF) & 99 & 164,14 & & \\
\hline & İktisat (İ̈BF) & 58 & 173,98 & & \\
\hline & Maliye (İ̈BF) & 58 & 165,30 & & \\
\hline & Bankacılık ve Finans (İ̈BF) & 18 & 137,75 & & \\
\hline \multirow{8}{*}{$\begin{array}{l}\text { Faktör 3: Muhasebe } \\
\text { Derslerinde Teknolojiye } \\
\text { Dayalı Anlatım }\end{array}$} & İşletme Yönetimi (MYO & 39 & 169,40 & \multirow{8}{*}{10,756} & \multirow{8}{*}{,150 } \\
\hline & Dış Ticaret (MYO) & 2 & 128,50 & & \\
\hline & $\begin{array}{c}\text { Sağlık Kurumları } \\
\text { İşletmeciliği (MYO) }\end{array}$ & 34 & 143,57 & & \\
\hline & $\begin{array}{l}\text { Muhasebe ve vergi } \\
\text { Uygulamaları (MYO) }\end{array}$ & 34 & 139,87 & & \\
\hline & İşletme (İİBF) & 99 & 185,15 & & \\
\hline & İktisat (İïBF) & 58 & 166,62 & & \\
\hline & Maliye (İ̈BF) & 58 & 182,59 & & \\
\hline & Bankacılık ve Finans (İ̈BF) & 18 & 198,25 & & \\
\hline
\end{tabular}


Tablo 9'da gösterilen Kruskal- Wallis testi sonuçlarına göre öğrencilerin muhasebe derslerinde teknoloji kullanımı algısı faktörü ile öğrencilerin bölümleri arasında anlamlı bir fark bulunmuştur $(\mathrm{p}<0,05)$. Fakat muhasebe derslerinde teknoloji kullanımı ile ilgili olumsuz algı faktörü ve muhasebe derslerinde teknolojiye dayalı anlatım faktörü ile öğrencilerin bölümleri arasında anlamlı bir fark tespit edilmemiştir $(\mathrm{p}<0,05)$.

Öğrencilerin gelecekte muhasebe alanında çalışmayı düşünme durumu ile muhasebe derslerinde teknoloji kullanımına ilişkin bakış açıları arasındaki durum:

Öğrencilerin muhasebe derslerinde teknoloji kullanımına ilişkin bakış açıları ile gelecekte muhasebe alanında çalışmayı düşünme durumu değişkenine ait Kruskal- Wallis testi sonuçları Tablo 10 'da gösterilmiştir.

Tablo 10: Öğrencilerin muhasebe derslerinde teknoloji kullanımına yönelik bakış açıları ile gelecekte muhasebe alanında çalışmayı düşünme durumu değişkenine ilişkin Kruskal- Wallis testi sonuçları

\begin{tabular}{|c|c|c|c|c|c|}
\hline & $\begin{array}{l}\text { Gelecekte Muhasebe } \\
\text { Alanında Çalışmayı } \\
\text { Düşünme Durumu }\end{array}$ & $\mathbf{N}$ & $\begin{array}{c}\text { Sira } \\
\text { Ortalaması }\end{array}$ & $\begin{array}{l}\text { Chi- } \\
\text { Square }\end{array}$ & $\mathbf{P}$ \\
\hline \multirow{3}{*}{$\begin{array}{l}\text { Faktör 1: Muhasebe } \\
\text { Derslerinde } \\
\text { Teknoloji Kullanımı } \\
\text { Algısı }\end{array}$} & Evet & 123 & 181,05 & \multirow{3}{*}{4,826} & \multirow{3}{*}{,090 } \\
\hline & Hayır & 83 & 151,27 & & \\
\hline & Kararsızım & 136 & 175,21 & & \\
\hline \multirow{3}{*}{$\begin{array}{l}\text { Faktör 2: Teknoloji } \\
\text { Kullanımı İle İlgili } \\
\text { Olumsuz Alg1 }\end{array}$} & Evet & 123 & 163,89 & \multirow{3}{*}{2,155} & \multirow{3}{*}{,340 } \\
\hline & Hayır & 83 & 167,25 & & \\
\hline & Kararsızım & 136 & 180,98 & & \\
\hline \multirow{3}{*}{$\begin{array}{l}\text { Faktör 3: Muhasebe } \\
\text { Derslerinde } \\
\text { Teknolojiye Dayalı } \\
\text { Anlatım }\end{array}$} & Evet & 123 & 177,67 & \multirow{3}{*}{,941 } & \multirow{3}{*}{,625 } \\
\hline & Hayır & 83 & 164,35 & & \\
\hline & Kararsızım & 136 & 170,29 & & \\
\hline
\end{tabular}

Tablo 10'da gösterilen Kruskal- Wallis testi sonuçlarına göre öğrencilerin muhasebe derslerinde teknoloji kullanımına ilişkin bakış açıları ile öğrencilerin gelecekte muhasebe alanında çalışmayı düşünme durumları arasında anlamlı bir fark tespit edilmemiştir $(\mathrm{p}<0,05)$.

Öğrencilerin muhasebe derslerini uzaktan eğitim yöntemi ile almayı düşünme durumu ile muhasebe derslerinde teknoloji kullanımına ilişkin bakış açıları arasındaki durum:

Öğrencilerin muhasebe derslerinde teknoloji kullanımına ilișkin bakış açıları ile muhasebe derslerini uzaktan eğitim ile almayı düşünme durumu değişkenine ait Kruskal- Wallis testi sonuçları Tablo 11'de gösterilmiştir. 
Tablo 11: Öğrencilerin muhasebe derslerinde teknoloji kullanımına yönelik bakış açıları ile muhasebe derslerini uzaktan eğitim ile almayı düşünme durumu değişkenine ilişkin Kruskal- Wallis testi sonuçları

\begin{tabular}{|c|c|c|c|c|c|}
\hline & $\begin{array}{c}\text { Muhasebe Derslerini } \\
\text { Uzaktan Eğitim İle Almayı } \\
\text { Düşünme Durumu }\end{array}$ & $\mathbf{N}$ & $\begin{array}{c}\text { Sira } \\
\text { Ortalaması }\end{array}$ & Chi-Square & $\mathbf{P}$ \\
\hline \multirow{3}{*}{$\begin{array}{l}\text { Faktör 1: Muhasebe } \\
\text { Derslerinde Teknoloji } \\
\text { Kullanımı Algısı }\end{array}$} & Evet & 47 & 163,68 & \multirow{3}{*}{, 572} & \multirow{3}{*}{, 751} \\
\hline & Hayır & 258 & 171,70 & & \\
\hline & Kararsızım & 37 & 180,04 & & \\
\hline \multirow{3}{*}{$\begin{array}{l}\text { Faktör 2: Teknoloji } \\
\text { Kullanımı İle İlgili } \\
\text { Olumsuz Alg1 }\end{array}$} & Evet & 47 & 171,44 & \multirow{3}{*}{,297 } & \multirow{3}{*}{, 862} \\
\hline & Hayır & 258 & 170,33 & & \\
\hline & Kararsızım & 37 & 179,74 & & \\
\hline \multirow{3}{*}{$\begin{array}{l}\text { Faktör 3: Muhasebe } \\
\text { Derslerinde } \\
\text { Teknolojiye Dayalı } \\
\text { Anlatım }\end{array}$} & Evet & 47 & 170,95 & \multirow{3}{*}{,931 } & \multirow{3}{*}{,628 } \\
\hline & Hayır & 258 & 169,50 & & \\
\hline & Kararsızım & 37 & 186,18 & & \\
\hline
\end{tabular}

Tablo 11'de gösterilen Kruskal- Wallis testi sonuçlarına göre öğrencilerin muhasebe derslerinde teknoloji kullanımına ilişkin bakış açıları ile öğrencilerin muhasebe derslerini uzaktan eğitim yöntemi ile almayı düşünme durumları arasında anlamlı bir fark bulunmamıştır $(p<0,05)$.

Öğrencilerin kişisel bilgisayara sahip olma durumu ile muhasebe derslerinde teknoloji kullanımına ilişkin bakış açıları arasındaki durum:

Öğrencilerin muhasebe derslerinde teknoloji kullanımına yönelik bakış açıları ile kişisel bilgisayara sahip olma durumu değişkenine ilişkin Mann- Whitney U testi sonuçları Tablo 12'de gösterilmiştir.

Tablo 12: Öğrencilerin muhasebe derslerinde teknoloji kullanımına yönelik bakış açıları ile kişisel bilgisayara sahip olma durumu değişkenine ilişskin Mann- Whitney U testi sonuçları

\begin{tabular}{|c|c|c|c|c|c|c|c|}
\hline & $\begin{array}{c}\text { Kişisel } \\
\text { Bilgisayara } \\
\text { Sahip Olma } \\
\text { Durumu } \\
\end{array}$ & $\mathbf{N}$ & $\begin{array}{c}\text { Sira } \\
\text { Ortalaması }\end{array}$ & $\begin{array}{c}\text { Sira } \\
\text { Toplamı }\end{array}$ & $\mathbf{U}$ & $\mathbf{Z}$ & $\mathbf{P}$ \\
\hline \multirow{2}{*}{$\begin{array}{l}\text { Faktör 1: } \\
\text { Muhasebe } \\
\text { Derslerinde } \\
\text { Teknoloji } \\
\text { Kullanım Algis1 }\end{array}$} & Evet & 228 & 177,09 & 40376,00 & \multirow{2}{*}{11722,000} & \multirow{2}{*}{$-1,480$} & \multirow{2}{*}{,139 } \\
\hline & Hayır & 114 & 160,32 & 18277,00 & & & \\
\hline \multirow{2}{*}{$\begin{array}{l}\text { Faktör 2: } \\
\text { Teknoloji } \\
\text { Kullanımı İle } \\
\text { İlgili Olumsuz } \\
\text { Alg1 }\end{array}$} & Evet & 228 & 166,99 & 38073,50 & \multirow{2}{*}{11967,500} & \multirow{2}{*}{$-1,200$} & \multirow{2}{*}{,230 } \\
\hline & Hayır & 114 & 180,52 & 20579,50 & & & \\
\hline \multirow{2}{*}{$\begin{array}{l}\text { Faktör 3: } \\
\text { Muhasebe } \\
\text { Derslerinde } \\
\text { Teknolojiye } \\
\text { Dayalı Anlatım }\end{array}$} & Evet & 228 & 169,70 & 38692,50 & \multirow{2}{*}{12586,500} & \multirow{2}{*}{,- 477} & \multirow{2}{*}{ 633 } \\
\hline & Hayır & 114 & 175,09 & 19960,50 & & & \\
\hline
\end{tabular}


Tablo 12'de gösterilen Mann-Whitney U testi sonuçlarına göre, öğrencilerin muhasebe derslerinde teknoloji kullanımına ilişkin bakış açıları ile kişisel bilgisayara sahip olma durumu arasında anlamlı bir fark bulunmamıştır $(\mathrm{p}<0,05)$.

Öğrencilerin muhasebe derslerine çalışırken internet sitelerinden yararlanma durumu ile muhasebe derslerinde teknoloji kullanımına ilişkin bakış açıları arasındaki durum:

Öğrencilerin muhasebe derslerinde teknoloji kullanımına yönelik bakış açıları ile muhasebe derslerine çalışırken internet sitelerinden yararlanma durumu değişkenine ilişkin Mann- Whitney U testi sonuçları Tablo 13'de gösterilmiştir.

Tablo 13: Öğrencilerin muhasebe derslerinde teknoloji kullanımına yönelik bakış açıları ile muhasebe derslerine çalışırken internet sitelerinden yararlanma durumu değişkenine ilişkin Mann- Whitney U

\begin{tabular}{|c|c|c|c|c|c|c|c|}
\hline \multicolumn{8}{|c|}{ testi sonuçları } \\
\hline & $\begin{array}{c}\text { Muhasebe } \\
\text { Derslerine } \\
\text { Çalşırken } \\
\text { İnternet } \\
\text { Sitelerinden } \\
\text { Yararlanma } \\
\text { Durumu } \\
\end{array}$ & $\mathbf{N}$ & $\begin{array}{c}\text { Sira } \\
\text { Ortalaması }\end{array}$ & $\begin{array}{c}\text { Sira } \\
\text { Toplamı }\end{array}$ & $\mathbf{U}$ & $\mathbf{Z}$ & $\mathbf{P}$ \\
\hline Faktör 1: & Evet & 176 & 172,39 & 30341,50 & \multirow{2}{*}{14450,500} & \multirow{2}{*}{,- 173} & \multirow{2}{*}{,863 } \\
\hline $\begin{array}{l}\text { Muhasebe } \\
\text { Derslerinde } \\
\text { Teknoloji } \\
\text { Kullanımı Algıs1 }\end{array}$ & Hayır & 166 & 170,55 & 28311,50 & & & \\
\hline Faktör 2: & Evet & 176 & 176,13 & 30999,00 & \multirow[b]{2}{*}{13793,000} & \multirow[b]{2}{*}{,- 897} & \multirow[b]{2}{*}{, 370} \\
\hline $\begin{array}{l}\text { Teknolojı } \\
\text { Kullanımı İle } \\
\text { İlgili Olumsuz } \\
\text { Alg1 }\end{array}$ & Hayır & 166 & 166,59 & 27654,00 & & & \\
\hline Faktör 3: & Evet & 176 & 173,71 & 30572,50 & \multirow{2}{*}{14219,500} & \multirow{2}{*}{,- 427} & \multirow{2}{*}{ 669 } \\
\hline $\begin{array}{l}\text { Muhasebe } \\
\text { Derslerinde } \\
\text { Teknolojiye } \\
\text { Dayalı Anlatım }\end{array}$ & Hayır & 166 & 169,16 & 28080,50 & & & \\
\hline
\end{tabular}

Tablo 13'de gösterilen Mann-Whitney U testi sonuçlarına göre, öğrencilerin muhasebe derslerinde teknoloji kullanımına ilişkin bakış açıları ile muhasebe derslerine çalışırken internet sitelerinden yararlanma durumu arasında anlamlı bir fark bulunmamıştır $(\mathrm{p}<0,05)$.

Öğrencilerin muhasebe sınavlarına çalışırken internet sitelerinden yararlanma durumu ile muhasebe derslerinde teknoloji kullanımına ilişkin bakış açıları arasındaki durum:

Öğrencilerin muhasebe derslerinde teknoloji kullanımına yönelik bakış açıları ile muhasebe sınavlarına çalışırken internet sitelerinden yararlanma durumu değişkenine ilişkin Mann- Whitney U testi sonuçları Tablo 14'de gösterilmiştir. 
Tablo 14: Öğrencilerin muhasebe derslerinde teknoloji kullanımına yönelik bakış açıları ile muhasebe sınavlarına çalışırken internet sitelerinden yararlanma durumu değişkenine ilişkin Mann- Whitney U

\begin{tabular}{|c|c|c|c|c|c|c|c|}
\hline & $\begin{array}{c}\text { Muhasebe } \\
\text { Sinavlarına } \\
\text { Çalışırken } \\
\text { İnternet } \\
\text { Sitelerinden } \\
\text { Yararlanma } \\
\text { Durumu }\end{array}$ & $\mathbf{N}$ & $\begin{array}{c}\text { Sira } \\
\text { Ortalaması }\end{array}$ & $\begin{array}{c}\text { Sira } \\
\text { Toplamı }\end{array}$ & $\mathbf{U}$ & $\mathbf{Z}$ & $\mathbf{P}$ \\
\hline \multirow{2}{*}{$\begin{array}{l}\text { Faktör 1: } \\
\text { Muhasebe } \\
\text { Derslerinde } \\
\text { Teknoloji } \\
\text { Kullanımı Algıs1 }\end{array}$} & Evet & 178 & 170,69 & 30383,00 & \multirow[t]{2}{*}{14452,000} & \multirow[t]{2}{*}{,- 158} & \multirow[t]{2}{*}{875} \\
\hline & Hayır & 164 & 172,38 & 28270,00 & & & \\
\hline \multirow{2}{*}{$\begin{array}{l}\text { Faktör 2: } \\
\text { Teknoloji } \\
\text { Kullanım İle İlgili } \\
\text { Olumsuz Alg1 }\end{array}$} & Evet & 178 & 181,52 & 32311,00 & \multirow[t]{2}{*}{12812,000} & \multirow[t]{2}{*}{$-1,963$} & \multirow[t]{2}{*}{,050 } \\
\hline & Hayır & 164 & 160,62 & 26342,00 & & & \\
\hline \multirow{2}{*}{$\begin{array}{l}\text { Faktör 3: } \\
\text { Muhasebe } \\
\text { Derslerinde } \\
\text { Teknolojiye } \\
\text { Dayalı Anlatım }\end{array}$} & Evet & 178 & 169,24 & 30125,50 & \multirow[t]{2}{*}{14194,500} & \multirow[t]{2}{*}{,- 441} & \multirow[t]{2}{*}{,659 } \\
\hline & Hayır & 164 & 173,95 & 28527,50 & & & \\
\hline
\end{tabular}

Tablo 14'de gösterilen Mann-Whitney U testi sonuçlarına göre, öğrencilerin muhasebe derslerinde teknoloji kullanımına ilişkin bakış açıları ile muhasebe sınavlarına çalışırken internet sitelerinden yararlanma durumu arasında anlamlı bir fark bulunmamıştır $(\mathrm{p}<0,05)$.

Öğrencilerin bir muhasebe paket programı kullanma durumu ile muhasebe derslerinde teknoloji kullanımına ilişkin bakış açıları arasındaki durum:

Öğrencilerin muhasebe derslerinde teknoloji kullanımına yönelik bakış açıları ile bir muhasebe paket programı kullanma durumu değişkenine ilişkin Mann- Whitney U testi sonuçları Tablo 15'de gösterilmiştir.

Tablo 15: Öğrencilerin muhasebe derslerinde teknoloji kullanımına yönelik bakış açıları ile bir muhasebe paket programı kullanma durumu değişkenine ilişkin Mann- Whitney U testi sonuçları

\begin{tabular}{|c|c|c|c|c|c|c|c|}
\hline & $\begin{array}{c}\text { Bir Muhasebe } \\
\text { Paket Programı } \\
\text { Kullanma } \\
\text { Durumu } \\
\end{array}$ & $\mathbf{N}$ & $\begin{array}{c}\text { Sira } \\
\text { Ortalaması }\end{array}$ & $\begin{array}{c}\text { Sira } \\
\text { Toplamı }\end{array}$ & $\mathbf{U}$ & $\mathbf{Z}$ & $\mathbf{P}$ \\
\hline \multirow{2}{*}{$\begin{array}{l}\text { Faktör 1: Muhasebe } \\
\text { Derslerinde Teknoloji } \\
\text { Kullanımı Algıs1 }\end{array}$} & Evet & 41 & 164,94 & 6762,50 & \multirow{2}{*}{5901,500} & \multirow{2}{*}{,- 453} & \multirow{2}{*}{,650 } \\
\hline & Hayır & 301 & 172,39 & 51890,50 & & & \\
\hline \multirow{2}{*}{$\begin{array}{l}\text { Faktör 2: Teknoloji } \\
\text { Kullanımı İle İlgili } \\
\text { Olumsuz Alg1 }\end{array}$} & Evet & 41 & 177,62 & 7282,50 & \multirow{2}{*}{5919,500} & \multirow{2}{*}{,- 425} & \multirow{2}{*}{,671 } \\
\hline & Hayır & 301 & 170,67 & 51370,50 & & & \\
\hline \multirow{2}{*}{$\begin{array}{l}\text { Faktör 3: Muhasebe } \\
\text { Derslerinde } \\
\text { Teknolojiye Dayalı } \\
\text { Anlatım }\end{array}$} & Evet & 41 & 153,07 & 6276,00 & \multirow{2}{*}{5415,000} & \multirow{2}{*}{$-1,277$} & \multirow{2}{*}{,201 } \\
\hline & Hayır & 301 & 174,01 & 52377,00 & & & \\
\hline
\end{tabular}


Tablo 15'de gösterilen Mann-Whitney U testi sonuçlarına göre, öğrencilerin muhasebe derslerinde teknoloji kullanımına ilişkin bakış açıları ile bir muhasebe paket programı kullanma durumu arasında anlamlı bir fark bulunmamıştır $(\mathrm{p}<0,05)$.

\section{Sonuç ve Öneriler}

Bilginin artık dijital ortamda paylaşıldığı günümüz iş dünyasında işletmeler de bu sisteme entegre olmak durumundadır. İşletmelerin önemli sistemlerinden birisi olan muhasebe sistemleri de paket yazılımların kullanılmasıyla başlayan ve günümüzde e- beyanname, e- fatura, e- defter gibi teknolojik uygulamaların kullanıldığı bir dönemden geçmektedir. Muhasebe uygulamalarını yürüten meslek mensuplarının bu teknolojileri kullanabilmeleri çok önemlidir. Teknolojik uygulamalar genellikle aktif iş hayatında öğrenilmekte ve uygulanmaktadır. Ancak üniversitelerin lisans veya ön lisans programlarında verilen muhasebe derslerini teknoloji kullanımı ile desteklemeleri, geleceğin meslek mensubu adayı olan öğrencilerin muhasebe uygulamalarında teknoloji kullanımı ile daha önceden tanışmalarına olumlu katkı sağlayacaktır.

Muhasebe dersi alan öğrencilerin muhasebede teknoloji kullanımına yönelik bakış açılarının değerlendirilmesi amacıyla yapılan çalışmada, ankete katılan öğrenciler derslerde daha çok taşınabilir bilgisayar, projeksiyon cihazı ve akıllı tahta kullanılması gerektiğini belirtmişler, aynı şekilde teknolojik yazılımlardan ise, paket muhasebe yazılımları, ofis uygulamaları ve internet tabanlı yazılımların kullanılması gerektiğini belirtmişlerdir.

Ankete katılan öğrencilere gelecekte muhasebe alanında çalışmayı isteyip istemedikleri sorusu yöneltilmiş ve evet cevabı verenlerin, hayır cevabı verenlerin ve kararsız olduklarını belirtenlerin sayısının birbirine yakın olduğu tespit edilmiştir. Öğrencilerin büyük çoğunluğu muhasebe derslerini uzaktan eğitim yöntemiyle almak istemediklerini belirtmişlerdir. Bu da öğrencilerin muhasebe derslerinin yüz yüze anlatılması gerektiğini düşündüklerini göstermektedir.

Ankete katılan öğrencilerin neredeyse tamamının akıllı cep telefonuna ve çoğunluğun ise, kişisel bilgisayara sahip olması durumu çalışmada tespit edilen bir başka bulgudur. Öğrencilerin büyük çoğunluğu üniversitelerinde kablosuz internet hizmeti bulunduğunu belirtmişler ancak, bu hizmetten yararlanma durumları açısından bakıldığında evet diyenlerle hayır diyenlerin oranının birbirine yakın olduğu görülmektedir. Ankete katılan öğrencilerin muhasebe derslerine ve sınavlarına çalışırken internet sitelerinden yararlanıp yararlanmadıkları sorulmuş ve sonuçlar birbirine oldukça yakın gerçekleşmiştir. Yani ankete katılan öğrenciler internet imkanı olmasına rağmen muhasebe derslerine ve sınavlarına çalışırken internet hizmetinden yararlanmamaktadır. Ayrıca öğrencilerin büyük çoğunluğu bir muhasebe paket programı kullanmadıklarını belirtmişlerdir.

Ayrıca, çalışmada ankete katılan öğrencilerin sırasıyla en çok muhasebe yazılımlarının ayrı bir ders olarak anlatılması gerektiği, muhasebe derslerinde ders konularının sınıfta anlatıldıktan sonra konu ile ilgili ders notlarının internet ortamında da paylaşılması gerektiği, muhasebe dersleri veren öğretim üyelerinin eğitimle ilgili yeni teknolojileri takip etmesi gerektiği ve teknolojik ürünlerin kullanımı ile dersleri takip etmenin daha kolay olacağı ifadelerine önem verdikleri tespit edilmiştir.

Çalışmada öğrencilerin bölümleri, ortalamaları ve sınıfları ile muhasebe derslerinde teknoloji kullanımına yönelik bakış açıları arasında istatistiki olarak anlamlı bir fark bulunmuştur. Yani öğrencilerin lisans veya ön lisans öğrencisi olmaları ya da okudukları bölüme göre verdikleri cevaplar anlamlı bir şekilde farklılaşmaktadır. Aynı şekilde öğrencilerin düşük ya da yüksek ortalamaya sahip olmaları ile muhasebede teknoloji kullanımı hakkındaki görüşleri anlamlı bir şekilde değişmektedir. Aynı şekilde ankete katılan öğrencilerin, birinci sınıfta olmalarının ya da mezuniyet aşamasına gelmiş olmaları durumunun, verdikleri cevapları anlamlı bir şekilde değiştirdiği görülmektedir. 


\section{KAYNAKÇA}

Bekçi, İ.; Titiz, İ. \& Ömürbek, N. (2006). Muhasebe Eğitimi Alan Öğrencilerin Bilgisayarlı Muhasebe Dersine Bakış Açılarına İlişskin Bir Araştırma, Muhasebe ve Finansman Dergisi, Sayı 29, 166175.

Cameron, C. \& Dickfos, J. (2014). 'Lights, Camera, Action!' Video Technology and Students' Perceptions of Oral Communication in Accounting Education, Accounting Education: an international journal, 23(2), 135-154.

Can, A. V. \& Demirci, Ş. D. (2016). Uluslararası Muhasebe Eğitim Standardı 2 Muhasebe Eğitim Programlarının İçeriğine Uyum: Sakarya Üniversitesi Örneği, Uluslararası Yönetim İktisat ve İşletme Dergisi, 16 Özel Sayısı, 319- 338.

Çankaya, F. \& Dinç, E. (2009). Powerpoint ve Klasik Usulde Muhasebe Eğitimi Alan Öğrenciler Arasındaki Farklılıkların Tespiti: Karadeniz Teknik Üniversitesinde Bir Araştırma, Kocaeli Üniversitesi Sosyal Bilimler Enstitüsü Dergisi, 17(1), 28 - 52.

Eloff, A.M. (2016). The İntegration of Information and Information Technology in Accounting Education: Effects On Student Performance, Journal of Economic and Financial Sciences, $9(2), 409-425$.

Erol Fidan, M. (2012). Üniversitelerde Muhasebe Dersini Powerpoint Sunumu ve Klasik Yöntem İle Alan Öğrenciler Arasındaki Farklılıklar: Bilecik Üniversitesi Örneği, Yaşar Üniversitesi Dergisi, 25(7), 4281-4306.

Erol Fidan, M. \& Subaşı, Ş. (2015). Türkiye'deki Muhasebe Öğretim Elemanlarının Sayısal Çağda Teknoloji Kullanımına İlişkin Durum Tespiti, Çankırı Karatekin Üniversitesi Sosyal Bilimler Enstitüsü Dergisi, 6(1), 85- 112.

Erol Fidan, M.; Aslan, Ü. \& Subaşı, Ş. (2015). Muhasebe Derslerinde Teknoloji Kullanımı İle İlgili Öğrenci Görüşleri, Journal of Accounting, Finance and Auditing Studies 1(2), 34-61.

Güneş, E.; Yüksel, M. \& Kaya, H. P. (2017). Muhasebe Eğitimi Alan Lisans Öğrencilerinin Bilgi Ve İletişim Teknolojilerine Yönelik Tutumları, Ahi Evran Üniversitesi Kırşehir Eğitim Fakültesi Dergisi, 18(1),367-382.

Güney, S. \& Kaya, A. (2018). Teknolojik Gelişmelerin Muhasebe Eğitimi Üzerinde Etkileri: Öğretim Elemanları Üzerinde Bir Uygulama, Turkish Studies Economics, Finance and Politics, Cilt $13 / 14,261-282$.

Hacırüstemoğlu, R. (2008). Bilgi Çağında Muhasebe Eğitimi, Muhasebe Bilim Dünyası Dergisi, 10(3), $1-6$.

Hatunoğlu, Z. (2006). Muhasebe Eğitiminde Bilgi Teknolojisi Kullanımının Sunum Kalitesine Olan Etkilerinin Tespitine İlişkin Bir Araştırma, Muhasebe ve Finansman Dergisi, Sayı 30, 190200.

Kızıl, C.; Şeker, S. E. \& Bozan, D. (2014). Bilgi Teknolojileri Ve Bilgisayar Kullanımının Öğrencilerin Muhasebe Dersindeki Başarısına Etkisi, Alphanumeric Journal, 2(2), 77- 97.

Öztürk, S. \& Kutlu, H. A. (2017). Muhasebe Eğitiminde Teknoloji Kullanılmasına Öğrencilerin Bakışı: Kafkas Üniversitesi’nde Bir Araştırma, Muhasebe Bilim Dünyası Dergisi, 19(3), 781 799.

Öztürk, M. S. \& Erdoğan, M. (2018). Muhasebe Eğitiminde Bilgi Teknolojileri Kullanımı Üzerine Bir Araştırma, Akdeniz İ.İ.B.F. Dergisi, 38, 173-196. 
Temelli, F. (2018). İİBF Öğrencilerinin Muhasebe Derslerinde Teknoloji Kullanımı İle İlgili Görüşleri: Ağrı İbrahim Çeçen Üniversitesi Örneği, Muhasebe Bilim Dünyası Dergisi Özel Say1 20, 701- 720.

Yüksel, M. \& Olpak, Y. Z. (2014). Facebook'un Eğitimde Kullanılması: Muhasebe Eğitiminde Bir Uygulama, Ahi Evran Üniversitesi Kırşehir Eğitim Fakültesi Dergisi, 15(1), 171-186. 